\title{
Board of Directors Attributes and Sustainability Performance in the Energy Industry
}

\author{
Syeda Saba Nazir GARDAZI ${ }^{1}$, Ahmad Fahmi Sheikh HASSAN² ${ }^{2}$ Jalila Binti JOHARI $^{3}$ \\ Received: September 01, 2020 Revised: October 26, 2020 Accepted: November 05, 2020
}

\begin{abstract}
The board of directors play an important role in corporate climate strategy-making and decisions but might also compromise environmental policies to minimize agency cost. This study critically investigates the relationship between the attributes of the board of directors and the degree of sustainability performance for the energy sector as discussed in the literature. Our study cumulates existing knowledge offering important characteristics for a balanced board structure to increase the board's effectiveness in adopting sustainable initiatives that could reduce the adverse impact of an energy corporation's operation on the environment. Crucial attributes of the board of directors deemed to be positively associated with the commitment to reduce carbon footprint in the environment have been identified. Based on our extensive analysis of the literature we propose a conceptual framework that measures the influence of the board of directors' attributes on corporate environmental and social sustainability performance. The proposed framework will be useful as an initial step for top management and regulators to gain a better understanding of the balanced board structure required to achieve the social and environmental sustainability performance of corporations. Further, this paper contributes to a body of knowledge about how the board of directors could play a crucial role in monitoring social and environmental threats.
\end{abstract}

Keywords: Environmental Sustainability Performance, Social Sustainability Performance, Energy Corporation, Corporate Governance, Board of Directors

JEL Classification Code: G30, G34, Q01

\section{Introduction}

The board of directors is the backbone of corporate governance structure and is responsible for protecting the interests of stakeholders of the corporations through directing its operations and supporting its decision making. They also determine corporate policies of corporations,

${ }^{1}$ First Author. PhD Student, School of Business and Economics, Universiti Putra Malaysia (UPM), Selangor, Malaysia.

Email: Nazirsaba91@gmail.com

${ }^{2}$ Corresponding Author. Associate Professor, School of Business and Economics, Universiti Putra Malaysia (UPM), Malaysia [Postal Address: Serdang, 43400 Seri Kembangan, Selangor, Malaysia] Email: ahmadfahmi@upm.edu.my

${ }^{3}$ Senior Lecturer in School of Business and Economics, Universiti Putra Malaysia (UPM), Serdang, 43400 Seri Kembangan, Selangor, Malaysia. Email: jjohari@upm.edu.my

(c) Copyright: The Author(s)

This is an Open Access article distributed under the terms of the Creative Commons Attribution Non-Commercial License (https://creativecommons.org/licenses/by-nc/4.0/) which permits unrestricted non-commercial use, distribution, and reproduction in any medium, provided the original work is properly cited. decide on corporate issues, assure corporate profitability and return on stakeholders' investments. However, we argue that stakeholders have broader expectations from their large investments, for example, some focus on financial return only while others are also concerned about the adverse impact of corporations' operations on the environment. Hence, board climate change strategy and decision in favour of corporate profitably may affect different groups of stakeholder's needs in distinct way (Aminu and Salawudeen, 2019; Weiss, 2019). Since decision-makers are ultimately responsible for agency costs, the board decision might include environmental policies to minimize the agency costs. Recently, stakeholders have raised their concerns on the environmental damage caused by the corporation's business operations, especially in energy sectors due to fossil fuel burning, which adversely impacts global warming and climate change-related health risks. A study conducted in 2014 revealed that $81 \%$ of the energy supply globally was produced by burning fossil fuel (coal, oil, and gas), which causes a continuous rise of greenhouse gas (GHG) emissions in the environment (Henderson, 2016). 
Air pollution caused by the energy sectors proved to be the most significant cause of diseases and premature deaths. According to a recent study in 2015, total premature deaths due to air pollution were 9 million, while in the year 2012, 7 million people died due to air pollution globally (Landrigan et al., 2018). Therefore, the energy industry is not only expected to pay back their shareholders with high financial returns, but also need to become more resistant to environmental impacts which adversely affect their stakeholders' health and wellbeing (Joshi and Li, 2016). To address the environmental damage concerns of stakeholders, the energy industries must take full responsibility for their manufacturing processes and operations, ensuring sustainable practices and the wellbeing of their stakeholders. Good corporate governance must mitigate agency problems and guide executives to work in favour of a stakeholders' interests (Al-Hiyari, 2017; Nazir and Afza, 2018). Hence, corporations must adopt their policies to address the rapid changes in environmental needs such as climate change, global warming, GHG emissions, and pollution, which are damaging the environment and affect the stakeholder's interests directly or indirectly. However, studies that are available indicate that energy corporations are lagging in green initiatives (Chen et al., 2018; Daniel, 2018). The main reason for this is that many economists believe that integrating sustainable goals exceeds corporation costs. Others fear that implementing proposed solutions require corporations to build specific capabilities that will be expensive and inefficient. The general argument is that everyone gets benefited by reduced carbon emissions, while corporations or individuals pay the cost.

We argue that the board of director's propensity towards societal-welfare and well-being can broadly impact corporate climate change strategy and implementation of suitable development goals. While there has been a growing interest in studying the relationship between corporate governance and sustainable development, the studies on the composition of the board of directors and its response to environmental sustainability initiatives remains an issue in empirical and theoretical studies development (Naciti, 2019). Previous studies mainly investigate issues like, the composition of the board of directors, board independence, gender diversity, CEO duality, board size, and the impact on financial performance of service industries (consumers goods, health care, information technology, real estate, and telecommunication) (Chams and Garcia-Blandon, 2019; Sewpersadh, 2019). Since the prime focus of a corporation is to increase financial gain, achieve overall corporate objectives, and to create an excellent prospect for future opportunities, governance composition is mainly investigated for financial performance. Moreover, most empirical studies on corporate governance and profitability have been conducted on the financial performance of industrial corporations (Jackling and Johl, 2009; Ramdani and Witteloostuijn, 2010).
The objective of this study is to explore the association between board composition (directors' independence, board diversity, CEO duality, and board size) and corporate social and environmental sustainability performance in the energy industry. All energy resources such as fossil fuel, coal, oil, and natural gas have some impact on our environment in terms of damaging public health and global warming. By understanding current and potential environmental issues associated with each energy source, energy industry can take an appropriate step to minimize this impact. This study argues that board of directors play a crucial role in adopting effective strategies to reduce environmental impact caused by the production and consumption of different energy sources. This study contributes to the existing literature on the composition of the board of directors by extending the discussion from financial performance to environmental and social sustainability performance. We also developed a conceptual model that will be useful in formulating the initial steps for top management and regulators, especially in the oil and gas corporations who are interested in implementing corporate governance practices and transparent climate change-related strategies. Additionally, this study enhances the understanding of the structure of the board of directors and their role and it should be useful for public policymakers who are concerned about balanced board composition and environmental and social risks.

The next section presents a literature review of the energy sector, and the relationship between corporate governance and its sustainability performance. In Section 3, detailed literature is investigated on the composition of the board of directors to develop an integrated conceptual model. Finally, Section 4 concludes the study with future research.

\section{Literature Review}

The energy industry has become the central pillar of all economic activities across the world (Dube and Jaiswal, 2015). Over the past two decades, the destructive effects of the energy industry, such as release of GHG emissions, have been a cause of concern for many stakeholder groups, including investors, regulators, shareholders, and environmentalists. To achieve social support from various stakeholders, energy corporations must participate in social and environmental corporate practices (Florini and Saleem, 2011). A considerable number of studies have examined sustainability practices and environmental disclosure in the energy sector. For example, Del Mar Alonso-Almeida et al., (2014) suggest that to become more sustainable, energy corporations have to adopt the Global Reporting Initiative (GRI) framework, because these corporations are the primary source of polluting the environment. Similarly, Raufflet et al., (2014) indicate that corporations need to adopt international corporate social responsibility (CSR) 
frameworks and standards such as Global Compact and ISO 26000 to implement CSR practices in the oil, gas, and mining sectors for sustainability initiatives. Lu et al., (2019) determined corporate sustainability practices in energy utilities by using a framework of sustainability energy indicators in Baltic States and found that CSR is the first initiative to achieve sustainable development in the energy and utilities industry. Additionally, Thorne et al., (2014) stated that corporations engaged in the energy industry must have abundant knowledge related to environmental matters more than other sectors, such as consumer goods, the telecommunication industry, and insurance and banking sectors.

A few studies have focused on the corporate sustainability performance of the energy industry (Pietrosemoli and Monroy, 2013; Sartori et al., 2017). They suggest that corporations should focus on environmental, social and economic issues to improve sustainability performance in the energy sector. However, a lack of financial stability, market competition, and technical complexity are the main barriers of sustainability performance for corporations in the energy industry (Meijer et al., 2019). Sustainability performance and CSR can play a vital role in reducing corporate level fraud, such as corruption in the energy industry (Lu et al., 2019). Furthermore, renewable energy corporations have become vital to supporting sustainable development in mitigating the impact of climate change. For instance, Elum and Momodu (2017) explore how shifting from fossil fuel-based energy towards renewable energy sources can reduce problems of climate change and social equity.

An extensive body of research examined corporate sustainability initiatives and the financial performance of the energy industry. Sidhoum and Serra (2017) examined the relationship between sustainability initiatives and financial performance in the electric utility sector of the United States and found that there is a strong association between sustainability initiatives and financial performance suggesting that the adoption of environmentally friendly technologies may improve corporation financial health and efficiency in the energy sector. Similarly, Amacha and Dastane (2017) examined the strong relationship between sustainability practices and the financial performance in Malaysian oil and gas corporations and found that sustainability reporting positively impacts financial performance. A corporation without an effective internal governance structure cannot pursue corporate sustainability policies, strategies, and environmental risk (Hollindale et al., 2019). The board of directors, being a pivotal decision-maker of the corporation, is responsible and accountable for sustainability issues. However, past literature has documented limited evidence on the link between the board of directors attributes and sustainability performance, focusing mainly on the energy sector (Batruch, 2017; Shahbaz, et al., 2020). Most recently
Shahbaz et al., (2020) documented that the board of directors is positively linked with sustainability performance; a wellstructured corporate governance attribute such as the board of directors should lead to high sustainability commitments in the energy industry.

\subsection{Board of Directors and Sustainability Performance}

The board of directors is responsible for determining whether to invest or not, in sustainability performance (Rao and Tilt, 2016a). Agency theory, stakeholder theory, and resource dependency are three underpinning theories that can be used to explain the association between corporate governance attributes and sustainability performance. Agency theory states that the central role of the top leadership is to align a corporate's interest with shareholder interest (Jensen and Meckling, 1976). To align executives' and owners' goals, agency theory recommends separation of decision making between executives and owners. Akpan and Amran (2014), for example, used agency theory to identify the impact of independent directors and sustainability performance and found that independent directors within the board help to minimize the agency costs, monitor the agent decisions effectively, and supervise the executive directors.

According to the stakeholder theory, executives monitor the corporate operations on behalf of stakeholders to meet the financial, ethical, social, and moral needs of their stakeholders. In this context, Michelon and Parbonetti (2012) explored suitable corporate governance structures that enhance stakeholder relationships by nurturing corporate sustainability and argued that good corporate governance and sustainability is a balancing mechanism for better stakeholder management. They also explained that stakeholder theory is a bridge between corporate governance and sustainability initiatives to balance longterm stakeholders' and management goals.

Additionally, resource dependency theory explains that the basic functionality of the board of directors is the provision of resources, such as advice and counsel, link to other corporations, etc., and corporate performance (Hillman et al., 2000; Pfeffer \& Salancik, 2003). The resource dependency theory highlights the role of the board of directors in obtaining the resources needed by the corporation. The primary premise of the resource dependency theory is the requirement for environmental linkage among the corporation and external resources. Furthermore, resource dependency theory suggests that directors bring countless resources such as skills, information, legitimacy, and critical constituents like public policy decision-makers, customers, and suppliers (Kesner and Johnson, 1990; Pfeffer and Salancik, 2003). 
As empirical evidence, Hussain et al., (2018) studied the link between internal corporate governance attributes and sustainability performance and recognized that board composition plays a crucial role in nurturing the sustainability performance of the corporations. Similarly, Zaid et al., (2020) determined the relationship between corporate governance attributes and sustainability disclosures, and results show that corporate governance attributes have a decisive role in sustainability disclosure practices of energy corporations. Drawing on agency theory, stakeholder theory, and resource dependency theory, this study highlights the relationship between corporate governance and corporate sustainability performance by using one of the elements of corporate governance, i.e., the board of directors. More specifically, this study explores the influence of board of directors' attributes on corporate environmental and social sustainability performance. Hence, in the subsequent sections, we evaluate four attributes of the board of directors, namely, independent directors, board diversity, the duality of CEO, and board size. We also develop a conceptual framework to measure the association between the boards' attributes and their influence on social and environmental sustainability performance.

\section{The Board of Directors' Governance Attributes}

Prior studies suggest that independent directors more effectively monitor corporate operations and restrict the opportunistic behavior of the top management assumed by agency theory than a director who is connected to the corporation through business or family (Boateng et al., 2017; Fuzi et al., 2016). Similarly, a diverse board is more likely to share broader experiences and opinions and represent a discrete group of the stakeholders as assumed by stakeholder theory (DeBoskey et al., 2018). However, this study argues that climate change strategies and decisions made by top management of corporations affect a large group of stakeholders with conflicting financial and nonfinancial interests, therefore, the role of the board is critical in addressing issues raised by various stakeholders. In this section, we critically evaluate the four attributes of the board of directors (independent directors, board diversity, the duality of the CEO, and board size) to understand the board structure, which should be sufficiently representative of various stakeholders. We also identify the relationship between governance attributes and corporates' environmental and social sustainability performance.

\subsection{Board Independence}

An independent director is a person appointed to the board who is not taking part in the internal management of the corporation and has no family and business relationship with the corporation. The role of an independent director is to balance the interests of the shareholder and management. According to agency theory, the independent director on the board plays a vital role in controlling upper management decisions to protect stakeholder's rights (Fama and Jensen, 1983). The appointment of independent directors is a valuable structure of corporate governance that can lead to sound management (Said et al., 2009) by providing their expertise in the implementation and execution of sustainability initiatives and the monitoring of transparency in sustainability reporting (Wang, 2017). Having an insider governing board may be ineffective in their contributions and they might abuse their power for their own personal benefit. Therefore, much empirical research has been conducted that shows a positive relationship between independent directors and CSR (Barako and Brown, 2008; Ho and Wong, 2001). However, there might be a negative relationship between independent directors and corporate sustainability reporting due to other influential factors such as regulatory pressure on voluntary disclosure, boards' lack of expertise, and their newness to the business model (Emmanuel et al., 2018).

Moreover, a higher number of independent directors on the board have a positive relationship with social and environmental performance (Hussain et al., 2018). It has also been observed in previous studies that there is a positive link between CSR and independent directors (Karamanou and Vafeas, 2005; Prado-Lorenzo and Garcia-Sanchez, 2010). Similarly, a higher number of independent directors can convince corporations to follow best practices of environmental and social sustainability while maintaining the shareholders' interest (Jo and Harjoto, 2011; Nguyen and Nguyen, 2020). Specifically, Dube and Jaiswal (2015) examined how strengthening independent directors on the board improves sustainability performance within the energy industry. Based on previous research, we expect that board independence improves sustainability performance in the energy industry. Hence, we propose that a high number of independent directors on a board of directors has a positive relationship with environmental and social sustainability performance.

\subsection{Board Diversity}

Board diversity is a mixture of qualities, attributes, demography, and expertise of individual board members that could have an influence on corporate environmental policy (Rao and Tilt, 2016b). Agency and resource dependency theories are widely used to explain the relationship between board diversity and corporate social responsibilities. According to agency theory, the more diversity on the board, the better monitoring and management of the corporation's activities (Hassan and Marimuthu, 2016; 
Madhani, 2017). According to the resource dependency theory, diverse members bring more resources in terms of skills, expertise, advice, and counselling as well as access to the external market (Enache and Garcia-Meca, 2019; Fakir and Jusoh, 2020). Research showed that diversity in terms of gender, nationality, age, and higher education, improves corporate decision- making quality, especially as related to environmental and social activities, which leads to improving sustainability performance (Chams and GarciaBlandon, 2019; Rao and Tilt, 2016b).

Gender diversity of board members is expected to have a positive impact on corporate social responsibilities. Previous research has shown that having female members on the board of directors has positively influenced corporate sustainability performance (Emmanuel et al., 2018; Margaretha and Isnaini, 2014). Females generally contribute more to social intelligence and collaborative decision making as compared to their male counterparts (Bart and Mcqueen, 2013; Harjoto et al., 2015). Hence, they are more inclined to, moral obligations, affection, sympathy, and welfare that make them more effectively address social issues and stakeholder needs (Harjoto et al., 2015; Jain and Jamali, 2016; Tahir et al., 2020). Therefore, the presence of women on the board can enhance the effectiveness of stakeholder management. One such example is the involvement of women on the board of directors in Arab countries (Ibrahim and Hanefah, 2016; Issa and Fang, 2019). Despite rigid culture and gender discrimination, a positive association has been observed between the female members on a board and CSR. Based on empirical evidence, this study concluded that a corporation with a higher proportion of female directors exhibits higher environmental and social responsibility.

In terms of nationality, there are advantages and disadvantages of both an entirely homogeneous (local) or heterogeneous (foreign) board of directors. Having only local members on the board may negatively impact a corporation's long-term sustainability since locals are more emotionally attached to the corporation's short-term financial benefits, and their interests may prevail over the stakeholders' interests. Foreign directors appear less attached to short-term economic goals and more concerned with environmental and social performance (Webb, 2004). Studies have shown that having board diversity increases the financial performance of the corporation (Hambrick et al., 1996). Also, a foreign member on board positively influences the financial performance of the corporation (Masulis et al., 2012). A study on Indian financial companies shows that the influence of foreign members on the board is negatively related to sustainability exposure (Rafinda et al., 2018). However, agency theory on the relationship between corporate governance structure and CSR shows that corporations with a high proportion of foreign directors has a positive impact on CSR since they can monitor the behaviour of internal management and intervene when necessary (Dahya and McConnell, 2005).

Age is another characteristic that is widely studied under the diversity of the board members and top management. Age diversity of the board is related to the presence of different generation gaps with variance in personal values, moral judgment/reasoning, ethical and cultural values, as well as experience (Cucari et al., 2018). For example, older members usually exhibit more expertise, skills, and competency, whereas young members are generally more liberal, open-minded, energetic, and innovative. One may expect that having older members on the board means better decision making since older members have more developed moral reasoning as compared to younger counterparts. Many researchers found that a corporation has a higher score in sustainability rating when the age of board members is around 55 to 60 years (Cucari et al., 2018; Fernandes et al., 2019). A study on environmental reporting of 120 Malaysian corporations also noted that the older directors show more involvement in environmental disclosure, which is attributed to their higher level of maturity, exposure, and experience (Said et al., 2013). On the other hand, a few studies found that young directors express more concerns about the environment and have more knowledge about environmental issues (Diamantopoulos et al., 2003; Jansson et al., 2010). However, previous studies do not find any significant relationship between the age diversity of board members and sustainability disclosures (Barako and Brown, 2008; Giannarakis, 2014). In the light of this empirical evidence, this study suggests that having a balance of both older and younger members on the board positively influences a corporation's environmental and social suitability.

Another attribute which may impact on directors' decision making is their level of academic achievements. There is not much research on the relationship between the board's members' educational disciplines and achievements and their impact on social sustainability. However, Lewis et al., (2014) proposed that board members must have the relevant qualifications, i.e., an advanced degree in business, to disclose CSR issues adequately. Indeed, a board member with an advanced academic degree in a relevant field generally has more awareness and knowledge, which leads them to a better understanding of environmental strategies and sound decision-making. Other studies also showed a positive association between a board members' attainment of higher education in the relevant discipline and their concerns about disclosing environmental information (Kagzi and Guha, 2018; Shahab et al., 2019). In the light of empirical evidence, this study argues that a corporation whose boards have a higher proportion of directors with an advanced degree in Business Adminstration exhibit higher environmental and social responsibility. Based on empirical 
evidence and past literature, we expect that corporations with diverse board backgrounds (age, nationality, gender, and education level) enhance sustainability performance within the energy sector.

\subsection{CEO Duality}

Another vital component of the board is the chairperson and CEO who have the authority to control and manage corporate-level decisions. Usually, in a top-down governance structure, the chairperson monitors the board's function and delegates responsibilities to the CEO to manage the daily activities of a business. The duality of the CEO is when the same person works as a chairperson and CEO (Bear et al., 2010). According to agency theory, CEO duality moves power to a single person's hand, which leads to a conflict of interest among internal management, i.e., working on their own benefits rather than stakeholders, which in turn lead to poor corporate performance (Berger et al., 1997). Agency theory suggests that two different positions for chairperson on the board and CEO would liberate the board of directors from the administration (Michelon and Parbonetti, 2012). When the CEO takes the responsibility of the chairperson as well as management, it reduces board effectiveness in monitoring top management while managing day to day operations (Broye et al., 2017). Two different positions for the CEO and chairperson can increase the efficiency of management accountability, better corporation performance, and minimize agency cost (Morais et al., 2020).

Based on the arguments presented in this paper and agency theory, the separation of the board chairperson and CEO roles can improve sustainability performance within the energy sector. Thus, this paper proposes that the separation of the board chairperson and CEO roles exhibit a positive relationship on corporate environmental and social sustainability performance.

\subsection{Board Size}

The board size specifies the total number of directors serving on the board. Larger board size has positive as well as negative effects on a corporation's decision-making process. In the literature on corporate governance, board size has gained significant attention. According to resource dependency theory, large board sizes enhance corporate sustainability performance (Cheng, 2008), since more members bring more experience, knowledge, expertise, and a high level of value to the corporations well as to the society (Emmanuel et al., 2018). Also, resource dependency theory showed that a remarkable component in developing efficient and effective management in a corporation is the number of members serving on the board of directors. Therefore, the higher the corporation's need for cooperation, the larger the size of the board (Pfeffer, 1972), since members will have large external networks to rapidly capture scare resources and external market information (Kor and Sundaramurthy, 2009). A study conducted on the Indonesian mining industry, for example, showed that Western companies in Indonesia have a large board size, which showed more transparency in environmental disclosure (Trireksani and Djajadikerta, 2016).

On the other hand, a bigger board can hinder corporate productivity (Jensen, 1993) since the large board takes more time for collaboration and teamwork to reach a mutual decision. Also, a large board needs more negotiations and compromises as compared to a smaller board size (Kogan and Wallach, 1966; Moscovici and Zavalloni, 1969). According to agency theory, larger board sizes can also compromise the transparency and accountability of a corporation. Therefore, there is no precise concensus in the current literature about the relationship between board size and sustainability performance. However, this study believes that multi-cultural and multi-national corporations should take advantage of large board size to sufficiently represent interest of large group of stakeholders, whereas smaller corporations can benefit from smaller board sizes because smaller boards show more commitment to corporate sustainability in the energy sector than large companies.

\subsection{Conceptual Framework for Environmental and Social Sustainable Performance in the Energy Industry}

Based on the theoretical foundation of this paper and existing literature on the composition of the board of directors, this study has proposed an integrated conceptual framework to investigate the association between corporate governance attributes and the degree of sustainability practice by companies when their board of directors exhibit specific attributes discussed in the study and shown in Figure 1 below. The central premise of this framework is that the social and environmental sustainability performance of a corporation is a part of broader initiatives that strive to cope with environmental and climate change threats. The framework shows that human capital, i.e., the board of directors and a balanced governance structure, are significant variables to enhance environmental and social sustainability performance. Hence, it is useful for top management, especially for the board of directors of energy companies, to identify board characteristics that could improve corporate environmental activities, which could then positively impact the interests of distinct stakeholders' groups and the public's environmental concerns. 


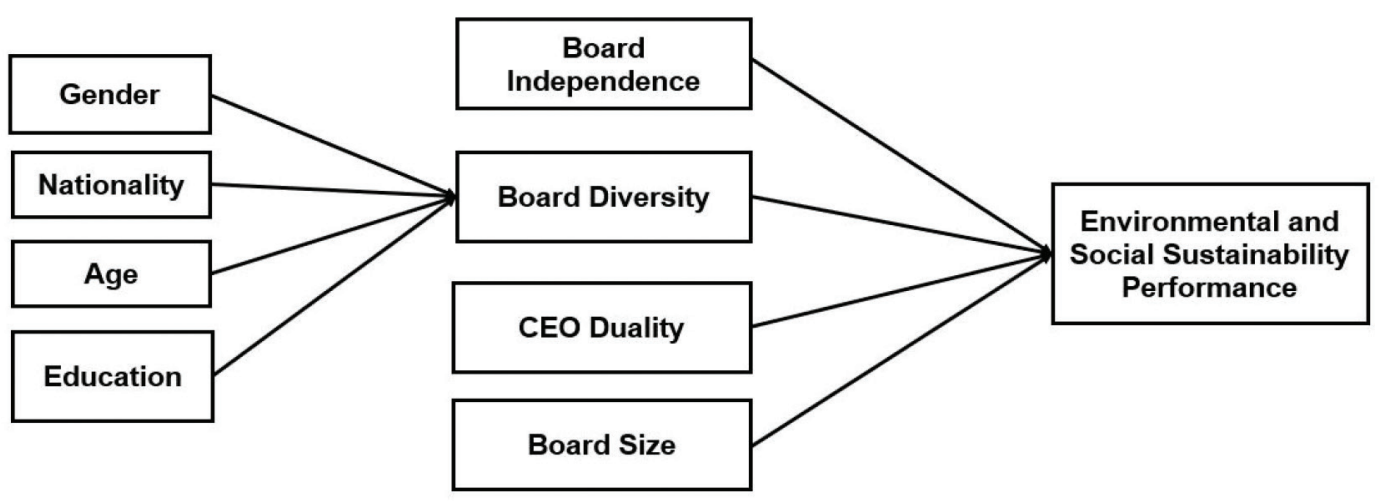

Figure 1: A Conceptual Framework of the Attributes of the Board of Directors' and Corporate Environmental and Social Sustainability Performance

The conceptual framework for balanced governance structure is a construct of four interrelated attributes, as appears in Figure 1. Each attribute performs a specific function within the environmental sustainability framework. An attribute of an independent member on the board seeks is that he/she will prevent biased decisions towards corporate profitability and promote the stakeholders' interests. Board diversity, in terms of gender, nationality, age, and higher education, will improve the quality of a corporation's decisions related to environmental and social activities, which in turn will lead to improving sustainability performance. The attribute of a separate chairperson and CEO will liberate the corporation from the conflicting interests of the $\mathrm{CEO}$ and the chairperson. The prime responsibility of the $\mathrm{CEO}$ is to focus on corporate profitability. In contrast, the chairperson will have a greater responsibility to satisfy the broader shareholders' needs of sustainability performance, which increases corporate accountability and transparency. The attribute of board size depends on a corporation's needs and size, and this study anticipates that multi-cultural corporations should take advantage of a large board size. In contrast, smaller corporations should take advantage of smaller board sizes where board of directors dedicates more time to tackle issues related to corporate environmental and social sustainability performance.

This conceptual framework should serve as an exciting first step for companies to increase their involvement in environmental activities. This study assumes that having a balanced board of directors' governance structure would better control the operations of the energy sector to mitigate environmental-related risks. Zheng et al., (2020) have proved that this type of framework could enhance companies' responses to environmental change-related risks and could offer financial and non-financial benefits (enhance companies' image and reputation) to the business. A diverse board represents and protects the environmental and the social needs of distinct stakeholders and demonstrates that their corporation is doing its part to solve society's environmental problems (Katmon et al., 2019).

\section{Conclusion}

The directors of large corporations are facing challenges from the shareholders and stakeholders alike to be proactive in figuring out disruptive market trends that are a result of environmental sustainability concerns. The board of directors play an essential role in defining strategies and policies to reduce social and environmental risks. The energy sector is considered an environmentally sensitive sector which attracts attention of the stakeholders. This study has theoretically evaluated the logical association between the board of directors' attributes and corporate environmental and social performance in the energy sector. Based on prior studies, this study has identified how specific attributes of a board member can positively influence a corporation's environmental and social sustainability performance. These attributes included an independent board of directors, board diversity, CEO duality, and board size. Based on strong evidence from our critical review of the literature, this study proposed an integrated conceptual framework as the first step in understanding corporate governance and their response to environmental and social sustainability performance. The proposed framework, with the presence of diverse board attributes, will be useful for top management and regulators who are interested in taking advantage of a balance in governance structure in implementing environmentally friendly initiatives, especially in the energy industry.

The board of directors of the energy industry should enable more effective engagement with investors and other stakeholders by fostering more active strategies to identify, 
measure, and disclose social and environmental risks. This will help the energy industry to integrate social and environmental strategies in their business model to protect the environment and social well-being. Furthermore, the board of directors in the energy industry need to participate in sustainability performance by investing in renewable energies, reducing GHG emissions, protecting biodiversity, tackling climate change, and contributing to society by providing clean, efficient, and reasonable energy for households and commercial use. Additionally, a balanced governance structure would demonstrate to companies' stakeholders that individual corporations are doing their part to solve society's social and environmental problems. We believe our study enriches the literature for an understanding of the complicated governance structure of corporates and is thereby useful for academics who are concerned with the influence of governance structure and environmental change control targets.

This study, however, has several limitations worth mentioning. First, this study only conceptually examined the association between corporate governance attributes and sustainability performance based on evidence from literature. Therefore, future studies could contribute to the current literature by empirically investigating the impact of corporate governance attributes on the sustainability performance of corporations. Secondly, the study is limited to critically reviewing a few corporate governance attributes (independent directors, board diversity, CEO duality, and board size). Future studies need to include other internal and external corporate governance attributes such as the influence of the sustainability committee and the director's interlock on the sustainability performance of the corporation. Similarly, the director's interlock could have large external networks to rapidly capture scare resources and external market information. Furthermore, it would be worth exploring other mediating or moderator variables such as technology, employees' motivation, and CSR strategy to strengthen further the board of directors' inclination towards the adaptation of sustainable environmental activities. Nevertheless, even with these limitations, this study provides several managerial implications for a corporation's board and presents future directions for research to create an empirical model on a corporations' governance structure and its environmental and social sustainability performance.

\section{References}

Akpan, E. O., \& Amran, N. A. (2014). Board characteristics and company performance: Evidence from Nigeria. Journal of Finance and Accounting, 2(3), 81-89. https://doi.org/10.11648/j. jfa.20140203.17
Al-Hiyari, A. (2017). A critical review of corporate governance reforms in Malaysia. Journal of Governance and Regulation, 1(6), 38-44. http://dx.doi.org/10.22495/jgr_v6_i1_p4

Amacha, E., \& Dastane, O. (2017). Sustainability practices as determinants of financial performance: A case of Malaysian corporations. The Journal of Asian Finance, Economics and Business, 4(2), 55-68. https://doi.org/10.13106/jafeb.2017

Aminu, I. M., \& Salawudeen, A. (2019). Board characteristics, dividend policy and shareholders' wealth of listed manufacturing companies in Nigeria. Journal of Applied Business and Economics, 21(9), 24-25. https://doi.org/10.33423/jabe. v21i9.2682

Barako, D. G., \& Brown, A. M. (2008). Corporate social reporting and board representation: Evidence from the Kenyan banking sector. Journal of Management and Governance, 12(4), 309. https://doi.org/10.1007/s10997-008-9053-x

Bart, C., \& Mcqueen, G. (2013). Why women make better directors. International Journal of Business Governance and Ethics, 8(1), 93-99. https://doi.org/10.1504/IJBGE.2013.052743

Batruch, C. (2017). Climate change and sustainability in the energy sector. The Journal of World Energy Law \& Business, 10(5), 444-463. https://doi.org/10.1093/jwelb/jwx024

Bear, S., Rahman, N., \& Post, C. (2010). The impact of board diversity and gender composition on corporate social responsibility and firm reputation. Journal of Business Ethics, 97(2), 207-221. https://doi.org/10.1007/s10551-010-0505-2

Berger, P. G., Ofek, E., \& Yermack, D. L. (1997). Managerial entrenchment and capital structure decisions. Journal of Finance, 52(4), 1411-1438. https://doi.org/10.1111/j.1540-6261.1997. tb01115.x

Boateng, A., Bi, X., \& Brahma, S. (2017). The impact of firm ownership, board monitoring on operating performance of Chinese mergers and acquisitions. Review of Quantitative Finance and Accounting, 49(4), 925-948. https://doi. org/10.1007/s11156-016-0612-y

Broye, G., Francois, A., \& Moulin, Y. (2017). The cost of CEO duality: Evidence from french leadership compensation. European Management Journal, 35(3), 336-350. https://doi. org/10.1016/j.emj.2017.01.007

Chams, N., \& Garcia-Blandon, J. (2019). Sustainable or not sustainable? The role of the board of directors. Journal of Cleaner Production, 226, 1067-1081. https://doi.org/10.1016/j. jclepro.2019.04.118

Chen, F., Ngniatedema, T., \& Li, S. (2018). A cross-country comparison of green initiatives, green performance and financial performance. Management Decision, 56(5), 1008-1032. https://doi.org/10.1108/MD-08-2017-0761

Cheng, S. (2008). Board size and the variability of corporate performance. Journal of Financial Economics, 87(1), 157-176. https://doi.org/10.1016/j.jfineco.2006.10.006 
Cucari, N., Esposito De Falco, S., \& Orlando, B. (2018). Diversity of board of directors and environmental social governance: Evidence from Italian listed companies. Corporate Social Responsibility and Environmental Management, 25(3), 250266. https://doi.org/10.1002/csr.1452

Dahya, J., \& McConnell, J. J. (2005). Outside directors and corporate board decisions. Journal of Corporate Finance, 11(12), 37-60. https://doi.org/10.1016/j.jcorpfin.2003.10.001

Daniel, O. (2018). The relationship between corporate social responsibility, corporate sustainability, and corporate financial performance. Doctoral dissertation, ProQuest Dissertations \& Theses Global. (Order No. 10976327).

DeBoskey, D., Luo, Y., \& Wang, J. (2018). Does board gender diversity affect the transparency of corporate political disclosure? Asian Review of Accounting, 26(4), 444-463. https://doi.org/10.1108/ARA-09-2017-0141

Del Mar Alonso-Almeida, M., Llach, J., \& Marimon, F. (2014). A closer look at the Global Reporting Initiative sustainability reporting as a tool to implement environmental and social policies: A worldwide sector analysis. Corporate Social Responsibility and Environmental Management, 21(6), 318335. https://doi.org/10.1002/csr.1318

Diamantopoulos, A., Schlegelmilch, B. B., Sinkovics, R. R., \& Bohlen, G. M. (2003). Can socio-demographics still play a role in profiling green consumers? A review of the evidence and an empirical investigation. Journal of Business Research, 56(6), 465-480. https://doi.org/10.1016/S0148-2963(01)00241-7

Dube, I., \& Jaiswal, N. (2015). Corporate governance in the energy sector. Jindal Global Law Review, 6(2), 143-178. https://doi. org/10.1007/s41020-015-0018-Z

Elum, Z. A., \& Momodu, A. (2017). Climate change mitigation and renewable energy for sustainable development in Nigeria: A discourse approach. Renewable and Sustainable Energy Reviews, 76, 72-80. https://doi.org/10.1016/j.rser.2017.03.040

Emmanuel, O., Uwuigbe, U., Teddy, O., Tolulope, I., \& Eyitomi, G. A. (2018). Corporate diversity and corporate social environmental disclosure of listed manufacturing companies in Nigeria. Problems and Perspectives in Management, 16(3), 229-244.

Enache, L., \& Garcia-Meca, E. (2019). Board composition and accounting conservatism: The role of business experts, support specialist and community influentials. Australian Accounting Review, 29(1), 252-265. https://doi.org/10.1111/auar.12279

Fakir, A., \& Jusoh, R. (2020). Board gender diversity and corporate sustainability performance: Mediating role of enterprise risk management. Journal of Asian Finance, Economics, and Business, 7(6), 351-363. https://doi.org/10.13106/jafeb.2020. vol7.no6.351

Fama, E. F., \& Jensen, M. C. (1983). Agency problems and residual claims. The journal of law and Economics, 26(2), 327-349.

Fernandes, S. M., Bornia, A. C., \& Nakamura, L. R. (2019). The influence of boards of directors on environmental disclosure.
Management Decision, 57(9), 2358-2382. https://doi. org/10.1108/MD-11-2017-1084

Florini, A., \& Saleem, S. (2011). Information disclosure in global energy governance. Global Policy, 2, 144-154. https://doi. org/10.1111/j.1758-5899.2011.00135.x

Fuzi, S. F. S., Halim, S. A. A., \& Julizaerma, M. (2016). Board independence and firm performance. Procedia Economics and Finance, 37, 460-465. https://doi.org/10.1016/S22125671(16)30152-6

Giannarakis, G. (2014). The determinants influencing the extent of CSR disclosure. International Journal of Law and Management, 56(5), 393-416. https://doi.org/10.1108/IJLMA-05-2013-0021

Hambrick, D. C., Cho, T. S., \& Chen, M.-J. (1996). The influence of top management team heterogeneity on firms competitive moves. Administrative science quarterly, 659-684. https://doi. org/10.2307/2393871

Harjoto, M., Laksmana, I., \& Lee, R. (2015). Board diversity and corporate social responsibility. Journal of Business Ethics, 132(4), 641-660. https://doi.org/10.1007/s10551-014-2343-0

Hassan, R., \& Marimuthu, M. (2016). Corporate governance, board diversity, and firm value: Examining large companies using panel data approach. Economics Bulletin, 36(3), 1737-1750.

Hillman, A. J., Cannella, A. A., \& Paetzold, R. L. (2000). The resource dependence role of corporate directors: Strategic adaptation of board composition in response to environmental change. Journal of Management Studies, 37(2), 235-256. https://doi.org/10.1111/1467-6486.00179

Ho, S. S., \& Wong, K. S. (2001). A study of the relationship between corporate governance structures and the extent of voluntary disclosure. Journal of International Accounting, Auditing and Taxation, 10(2), 139-156. https://doi.org/10.1016/ S1061-9518(01)00041-6

Hollindale, J., Kent, P., Routledge, J., \& Chapple, L. (2019). Women on boards and greenhouse gas emission disclosures. Accounting \& Finance, 59(1), 277-308. https://doi.org/10.1111/acfi. 12258

Hussain, N., Rigoni, U., \& Orij, R. P. (2018). Corporate governance and sustainability performance: Analysis of triple bottom line performance. Journal of Business Ethics, 149(2), 411-432. https://doi.org/10.1007/s10551-016-3099-5

Ibrahim, A. H., \& Hanefah, M. M. (2016). Board diversity and corporate social responsibility in Jordan. Journal of Financial Reporting and Accounting, 14(2), 279-298. https://doi. org/10.1108/JFRA-06-2015-0065

Issa, A., \& Fang, H.-X. (2019). The impact of board gender diversity on corporate social responsibility in the Arab Gulf states. Gender in Management: An International Journal, 34(7), 577-605. https://doi.org/10.1108/GM-07-2018-0087

Jackling, B., \& Johl, S. (2009). Board structure and firm performance: Evidence from India's top companies. Corporate Governance: An International Review, 17(4), 492-509. https:// doi.org/10.1111/j.1467-8683.2009.00760.x 
Jain, T., \& Jamali, D. (2016). Looking inside the black box: The effect of corporate governance on corporate social responsibility. Corporate Governance: An International Review, 24(3), 253273. https://doi.org/10.1111/corg.12154

Jansson, J., Marell, A., \& Nordlund, A. (2010). Green consumer behavior: Determinants of curtailment and eco-innovation adoption. Journal of Consumer Marketing, 27(4), 358-370. https://doi.org/10.1108/07363761011052396

Jensen, M. C. (1993). The modern industrial revolution, exit, and the failure of internal control systems. The Journal of Finance, $48(3), 831-880$.

Jensen, M. C., \& Meckling, W. H. (1976). Theory of the firm: Managerial behavior, agency costs and ownership structure. Journal of Financial Economics, 3(4), 305-360. https://doi. org/10.1016/0304-405X(76)90026-X

Jo, H., \& Harjoto, M. A. (2011). Corporate governance and firm value: The impact of corporate social responsibility. Journal of Business Ethics, 103(3), 351-383. https://doi.org/10.1007/ s10551-011-0869-y

Joshi, S., \& Li, Y. (2016). What is corporate sustainability and how do firms practice it? A management accounting research perspective. Journal of Management Accounting Research, 28(2), 1-11. https://doi.org/10.2308/jmar-10496

Katmon, N., Mohamad, Z. Z., Norwani, N. M., \& Al Farooque, O. (2019). Comprehensive board diversity and quality of corporate social responsibility disclosure: evidence from an emerging market. Journal of Business Ethics, 157(2), 447-481. https:// doi.org/10.1007/s10551-017-3672-6

Kagzi, M., \& Guha, M. (2018). Does board demographic diversity influence firm performance? Evidence from Indian-knowledge intensive firms. Benchmarking: An International Journal, 25(3), 1028-1058. https://doi.org/10.1108/BIJ-07-2017-0203

Karamanou, I., \& Vafeas, N. (2005). The association between corporate boards, audit committees, and management earnings forecasts: An empirical analysis. Journal of Accounting Research, 43(3), 453-486. https://doi.org/10.1111/j.1475679X.2005.00177.x

Kesner, I. F., \& Johnson, R. B. (1990). An investigation of the relationship between board composition and stockholder suits. Strategic Management Journal, 11(4), 327-336. https://doi. org/10.1002/smj.4250110408

Kogan, N., \& Wallach, M. A. (1966). Modification of a judgemental style through group interaction. ETS Research Bulletin Series, 1966(1), 1-27. https://doi.org/10.1002/j.2333-8504.1966. tb00136.x

Kor, Y. Y., \& Sundaramurthy, C. (2009). Experience-based human capital and social capital of outside directors. Journal of Management, 35(4), 981-1006. https://doi. org/10.1177/0149206308321551
Landrigan, P. J., Fuller, R., Acosta, N. J., Adeyi, O., Arnold, R., Balde, A. B., .. . Breysse, P. N. (2018). The Lancet Commission on pollution and health. The Lancet, 391(10119), 462-512. http://dx.doi.org/10.1016/

Lewis, B. W., Walls, J. L., \& Dowell, G. W. (2014). Difference in degrees: CEO characteristics and firm environmental disclosure. Strategic Management Journal, 35(5), 712-722. https://doi.org/10.1002/smj.2127

Lu, J., Ren, L., Yao, S., Qiao, J., Strielkowski, W., \& Streimikis, J. (2019). Comparative review of corporate social responsibility of energy utilities and sustainable energy development trends in the baltic states. Energies, 12(18), 1-21. https://doi.org/10.3390/ en 12183417

Madhani, P. M. (2017). Diverse roles of corporate board: Review of various corporate governance theories. The IUP Journal of Corporate Governance, 16(2), 7-28. https://ssrn.com/ abstract $=2981605$

Margaretha, F., \& Isnaini, R. (2014). Board diversity and gender composition on corporate social responsibility and firm reputation in Indonesia. Journal of Management and Entrepreneurship, 16(1), 1-8. https://doi.org/10.9744/ jmk.16.1.1-8

Masulis, R. W., Wang, C., \& Xie, F. (2012). Globalizing the boardroom. The effects of foreign directors on corporate governance and firm performance. Journal of Accounting and Economics, 53(3), 527-554. https://doi.org/10.1016/j. jacceco.2011.12.003

Meijer, L., Huijben, J., Van Boxstael, A., \& Romme, A. (2019). Barriers and drivers for technology commercialization by SMEs in the Dutch sustainable energy sector. Renewable and Sustainable Energy Reviews, 112, 114-126. https://doi. org/10.1016/j.rser.2019.05.050

Michelon, G., \& Parbonetti, A. (2012). The effect of corporate governance on sustainability disclosure. Journal of Management and Governance, 16(3), 477-509. https://doi. org/10.1007/s10997-010-9160-3

Morais, F., Kakabadse, A., \& Kakabadse, N. (2020). Leading through discontinuous change: A typology of problems and leadership approaches in UK boards. Long Range Planning, 53(2), 101870. https://doi.org/10.1016/j.lrp.2019.02.003

Moscovici, S., \& Zavalloni, M. (1969). The group as a polarizer of attitudes. Journal of Personality and Social Psychology, 12(2), 125. https://doi.org/10.1037/h0027568

Naciti, V. (2019). Corporate governance and board of directors: The effect of a board composition on firm sustainability performance. Journal of Cleaner Production, 237, 1-7. https:// doi.org/10.1016/j.jclepro.2019.117727

Nazir, M. S., \& Afza, T. (2018). Does managerial behavior of managing earnings mitigate the relationship between corporate governance and firm value? Evidence from an emerging 
market. Future Business Journal, 4(1), 139-156. https://doi. org/10.1016/j.fbj.2018.03.001

Nguyen, A. H., \& Nguyen, L. H. (2020). Determinants of sustainability disclosure: Empirical evidence from Vietnam. Journal of Asian Finance, Economics, and Business, 7(6), 7384. https://doi.org/10.13106/jafeb.2020.vol7.no6.073

Pfeffer, J. (1972). Size and composition of corporate boards of directors: The organization and its environment. Administrative Science Quarterly, 17(2), 218-228. https://doi. org/10.2307/2393956

Pfeffer, J., \& Salancik, G. R. (2003). The external control of organizations: A resource dependence perspective. Stanford, CA: Stanford University Press.

Pietrosemoli, L., \& Monroy, C. R. (2013). The impact of sustainable construction and knowledge management on sustainability goals. A review of the Venezuelan renewable energy sector. Renewable and Sustainable Energy Reviews, 27, 683-691. https://doi.org/10.1016/j.rser.2013.07.056

Prado-Lorenzo, J.-M., \& Garcia-Sanchez, I.-M. (2010). The role of the board of directors in disseminating relevant information on greenhouse gases. Journal of Business Ethics, 97(3), 391-424. https://doi.org/10.1007/s10551-010-0515-0

Rafinda, A., Rafinda, A., Witiastuti, R. S., Suroso, A., \& Trinugroho, I. (2018). Board diversity, risk and sustainability of bank performance: Evidence from India. Journal of Security \& Sustainability Issues, 7(4), 793-806. https://doi.org/10.9770/ jssi.2018.7.

Ramdani, D., \& Witteloostuijn, A. v. (2010). The impact of board independence and CEO duality on firm performance: A quantile regression analysis for Indonesia, Malaysia, South Korea and Thailand. British Journal of Management, 21(3), 607-627. https://doi.org/10.1111/j.1467-8551.2010.00708.x

Rao, K., \& Tilt, C. (2016a). Board composition and corporate social responsibility: The role of diversity, gender, strategy and decision making. Journal of Business Ethics, 138(2), 327-347. https://doi.org/10.1007/s10551-015-2613-5

Rao, K., \& Tilt, C. (2016b). Board diversity and CSR reporting: An Australian study. Meditari Accountancy Research, 24(2), 182-210. https://doi.org/10.1108/MEDAR-08-2015-0052

Raufflet, E., Cruz, L. B., \& Bres, L. (2014). An assessment of corporate social responsibility practices in the mining and oil and gas industries. Journal of Cleaner Production, 84, 256270. https://doi.org/10.1016/j.jclepro.2014.01.077

Rebecca M.Henderson, S. A. R., Polina Dekhtyar,Amram Migdal. (2016). Climate change in 2018: Implications for business. Harvard Business School Background Note. 317-032.

Said, R., Omar, N., \& Abdullah, W. N. (2013). Empirical investigations on boards, business characteristics, human capital and environmental reporting. Social Responsibility
Journal, 9(4), 534-553. https://doi.org/10.1108/SRJ-02-20120019

Said, R., Zainuddin, Y. H., \& Haron, H. (2009). The relationship between corporate social responsibility disclosure and corporate governance characteristics in Malaysian public listed companies. Social Responsibility Journal, 5(2), 212-226. https://doi.org/10.1108/17471110910964496

Sartori, S., Witjes, S., \& Campos, L. M. (2017). Sustainability performance for Brazilian electricity power industry: An assessment integrating social, economic and environmental issues. Energy Policy, 111, 41-51. https://doi.org/10.1016/j. enpol.2017.08.054

Sewpersadh, N. S. (2019). A theoretical and econometric evaluation of corporate governance and capital structure in JSE-listed companies. Corporate Governance: The International Journal of Business in Society, 19(5), 1063-1081. https://doi. org/10.1108/CG-08-2018-0272

Shahab, Y., Ntim, C. G., Chen, Y., Ullah, F., Li, H.-X., \& Ye, Z. (2019). CEO attributes, sustainable performance, environmental performance, and environmental reporting: New insights from upper echelons perspective. Business Strategy and the Environment, 20. http://dx.doi.org/10.2139/ssrn.3512591

Shahbaz, M., Karaman, A. S., Kilic, M., \& Uyar, A. (2020). Board attributes, CSR engagement, and corporate performance: What is the nexus in the energy sector? Energy Policy, 143, 111582. https://doi.org/10.1016/j.enpol.2020.111582

Sidhoum, A. A., \& Serra, T. (2017). Corporate social responsibility and dimensions of performance: An application to US electric utilities. Utilities Policy, 48, 1-11. https://doi.org/10.1016/j. jup.2017.06.011

Tahir, H., Rahman, M., \& Masri, R. (2020). Do board traits influence firms dividend payout policy? Evidence from Malaysia. Journal of Asian Finance, Economics, and Business, 7(3), 87-99. https://doi.org/10.13106/jafeb.2020.vol7.no3.87

Thorne, L., Mahoney, L. S., \& Manetti, G. (2014). Motivations for issuing standalone CSR reports: A survey of Canadian firms. Accounting, Auditing \& Accountability Journal, 27(4), 686714. https://doi.org/10.1108/AAAJ-07-2013-1393

Trireksani, T., \& Djajadikerta, H. G. (2016). Corporate governance and environmental disclosure in the Indonesian mining industry. Australasian Accounting, Business and Finance Journal, 10(1), 18-28. https://doi.org/10.14453/aabfj.v10i1.3

Wang, M. C. (2017). The relationship between firm characteristics and the disclosure of sustainability reporting. Sustainability, 9(4), 624. https://doi.org/10.3390/su9040624

Webb, E. (2004). An examination of socially responsible firms' board structure. Journal of Management and Governance, 8(3), 255-277. https://doi.org/10.1007/s10997-004-1107-0

Weiss, S. L. (2019). A governance solution to prevent the destruction of shareholder value in M\&A transactions. Available at SSRN 3317584 . 
Zaid, M. A., Abuhijleh, S. T., \& Pucheta-Martínez, M. C. (2020). Ownership structure, stakeholder engagement, and corporate social responsibility policies: The moderating effect of board independence. Corporate Social Responsibility and Environmental Management, 27(3), 1344-1360. https://doi. org/10.1002/csr. 1888
Zheng, S., He, C., Hsu, S. C., Sarkis, J., \& Chen, J. H. (2020). Corporate environmental performance prediction in China: An empirical study of energy service companies. Journal of Cleaner Production, 121395. https://doi.org/10.1016/j. jclepro.2020.121395 